\title{
Achieving HIV targets by 2030: the possibility of using debt relief funds for sustainable HIV treatment in sub-Saharan Africa
}

\section{Roland C. Abah ${ }^{1}$}

Published online: 3 August 2020

(c) Springer Nature Limited 2020

\begin{abstract}
This paper assesses the possibility of using debt relief funds to sustain HIV treatment in sub-Saharan Africa, suppress transmission, and reach global goals to quell the epidemic by 2030. The cost of providing antiretroviral treatment is a huge burden on African countries. Concerns for Africa's capacity to keep pace with global advances are well founded. By analysing levels of 'debt distress', health expenditure per capita, and HIV antiretroviral therapy requirements in sub-Saharan African countries, the need for innovative finance with international cooperation emerges clearly. In addition to the HIV epidemic, African countries may become more vulnerable to disasters and other public health diseases such as malaria, tuberculosis, Ebola and COVID-19, especially without alternatives to current means of financing. Relief from debt service payments could release funds for sub-Saharan African countries to support universal HIV antiretroviral treatment with sustainable results.
\end{abstract}

Keywords Sub-Saharan Africa · HIV treatment - Antiretroviral · Debt relief · Agenda $2030 \cdot$ COVID-19

\section{Introduction}

Despite the growing rate of government health spending across the world, sub-Saharan African governments support only one-third of health expenditures [1]. As the world advocates to accelerate progress to achieve HIV targets by 2030, fears deepen for Africa's capacity to keep pace. According to the United States (US) Congressional Research Service [2], Africa's substantial challenges could adversely affect

Electronic supplementary material The online version of this article (https://doi.org/10.1057/s4127 1-020-00238-x) contains supplementary material, which is available to authorized users.

Roland C. Abah

Rolann04@yahoo.com

1 National Agency for the Control of AIDS, Central Area, Abuja, Nigeria 
infrastructure and human capacity development given weak revenue generation and huge debt. Although Africa accounts for $15 \%$ of world population, the continent grapples with $25 \%$ of the global disease burden [3]. Africa may not be able to respond adequately to healthcare needs given strained budgets and competing priorities [3].

The World Health Organisation (WHO) advocates for African countries to increase per capita spending on health. The African Union declared in 2001 that African countries should allocate at least $15 \%$ of annual budgets to health in the Abuja Declaration. By 2012, only four sub-Saharan African countries (Liberia, Rwanda, Swaziland, and Zambia) had reached this target. As the WHO reported in 2014, out-of-pocket household expenditure for health in most African countries exceeded $20 \%$ of total health expenditure-contributing to impoverishment [4]. These economic constraints burden pursuit of universal health care, resilience, and preparedness for diseases of international public health concern such as HIV, tuberculosis, malaria, and more recently, Ebola and COVID-19. Public health professionals need to recognize the value of these important concepts and metrics and be part of finding the solution (see Glossaries of relevant terms).

Africa is a highly indebted continent. The African Development Bank (AfDB) [5] reported that a decline in 'concessional financing' from donor countries flattened 'revenue to gross domestic product' ratios in recent years; and, the 'expenditure to gross domestic product' ratios increased from 2008 through 2015. This situation forced many African governments into 'deficit financing'. According to the AfDB [5], a sharp rise in debt occurred when many African countries turned to 'international capital markets' for funds. Since the beginning of 2015 through 2018, most African currencies lost $20 \%$ to $40 \%$ of value against the US dollar [5]. The AfDB economic outlook document for 2019 [6] noted 16 countries' debt-to-GDP ratio dipped below $40 \%$, and 6 countries debt-to-GDP ratio exceeded $100 \%$. The 'debt sustainability classification' for 16 African countries reached debt distress levels; debt in many others has become unsustainable. With the slow pace of putting in place fiscal structures on the continent for increased government spending, prospects for economic growth to support human capital development and public health infrastructure are weak in many countries.

The 2019 International Debt Statistics report of the World Bank (WB) [7] noted sub-Saharan African countries accessed 15.5\% more debt externally; Nigeria and South Africa led external debt stock increase by $29 \%$ and $21 \%$, respectively. The WB also reported an $11 \%$ average increase in the external debt of other sub-Saharan countries [7]. Nigeria accounted for about $20 \%$ of Africa's GDP and nearly $75 \%$ of the economy of West Africa in 2019 [6]. In 2018, Nigeria's 'public debt' reached US\$73.2 billion; the AfDB described this as a moderate risk of debt distress but growing [6]. With growing debt in many of Africa's large economies, sustainable investments in human capital development will be unrealistic without logical, deliberate, and innovative financing.

Consistent antiretroviral treatment could, over time, allow an HIV positive person to achieve viral load suppression to undetectable levels-greatly reducing likelihood of transmission to another person. This scientific breakthrough led to a global policy by the World Health Organisation to treat everyone with HIV 
with antiretrovirals to prevent deaths related to HIV/AIDS and reduce the rate of new infections. However, the cost of antiretroviral therapy severely burdens African countries; local resources for HIV interventions have only increased marginally [8, 9]. Granich et al. observed that between 2009 and 2013, HIV spending for care and treatment in 38 high burden countries in Africa was less than $50 \%$ of that needed [8]. HIV financing for care and treatment could become a challenge in high burden countries that are nearly at debt distress levels. With this and claims from several sub-Saharan countries that they are already in debt distress, current health financing may not go far towards eliminating the disproportionate burden of disease in Africa.

This paper aims to explain why debt in sub-Saharan African countries challenges universal HIV antiretroviral treatment to end that epidemic. I suggest that reduction in debt, or suspension of loan repayments in sub-Saharan African countries, could release local funding to support HIV treatment-bolstered by evidence that persons on HIV treatment who attain undetectable viral limits may not transmit the virus to others. Increased funding could support sub-Saharan countries to scale up treatment to cover all requiring HIV treatment. Debt relief funds used effectively could accelerate this progress for HIV treatment in sub-Saharan Africa-with implications for other diseases of major public health import.

Note: I have provided a Glossary of specific terms at the end of the manuscriptwhere each term is listed in order of its appearance in the text.

\section{Methods}

This paper concentrates on sub-Saharan African countries using several measures, including economy size, debt profile, population size, health expenditure, and HIV burden. Annual reports on HIV percent prevalence for 1990-2017 are presented in Supplemental Table S1.

Specifically:

- 'Health expenditure per capita' was estimated as a ratio of the sum of total health expenditures from public and private sources and country population. Excluding water and sanitation, health expenditure usually covers health services, emergency aid related to health, nutrition, and family planning.

- Annual change in health expenditure per capita (HEPC) in sub-Saharan Africa from 2014 to 2017 was calculated based the exponential function:

$$
R=\left\{\left(\mathrm{HEPC}_{2017} / \mathrm{HEPC}_{2014}\right)^{1 / 3}-1\right\} \times 100 \%
$$

- Annual cost of antiretroviral therapy required by sub-Saharan countries was calculated by multiplying the estimated cost of treating one person (US\$150 per person) annually by the estimated number of people living with HIV derived from the HIV prevalence rate of countries. 
The countries are classified as 'low- and middle-income countries' (LMICs). Most residents in sub-Saharan African countries (in 4 regions: west, east, central and south) average incomes at or below US\$1 per day.

Data come mainly from secondary sources, including reports from global and regional financial, health coordinating, and data management institutions such as the World Bank, African Development Bank, World Health Organisation, UNAIDS and from journal papers and research reports.

To analyse HIV prevalence and debt data of sub-Saharan African countries, I conducted descriptive statistical analysis, and estimation of basic statistics measures and trends in Microsoft Excel.

\section{Results}

\section{HIV epidemic in sub-Saharan Africa}

HIV/AIDS is a leading cause of death in Africa and compromises global efforts to control the epidemic. Recent reviews show HIV funding in decline, and the world not on track to end this epidemic [10]. Other major diseases, such as malaria, tuberculosis, Ebola, and more recently COVID-19, substantially increase the fiscal burden on many sub-Saharan African countries. Despite increasing coverage of antiretroviral treatment and a declining rate of HIV/AIDS deaths, $60 \%$ of persons living with HIV in west and central Africa still lack antiretroviral treatment; in east and southern Africa treatment still does not reach about 34\% [10]. HIV accounts for the largest part of the disease burden in Africa, and about $71 \%$ of the global epidemic.

Over 28 years (1990-2017), HIV prevalence in sub-Saharan Africa has remained above $2 \%$ in 18 countries and the mean prevalence over the period was above $2 \%$ in 22 countries (Table 1). Despite a decline between 1990 and 2017 in 11 countries, HIV prevalence increased in 20 sub-Saharan Africa countries between 1990 and 2017. In order of mean prevalence between 1990 and 2017, Eswatini (22.2\%), Botswana (21.9\%), Zimbabwe (19.6\%), Zambia (13.1\%), and South Africa (13\%) experienced the highest increases. Low variance below 10 was recorded for HIV prevalence from 1990 to 2017 in 25 countries meaning the prevalence in those countries were consistently close to the mean HIV prevalence.

\section{Public HIV spending in sub-Saharan Africa}

According to UNAIDS [12], domestic resources for HIV interventions increased in sub-Saharan Africa by 2017. Other sources of funds in 2017 included the US President's Emergency Programme for AIDS Relief (PEPFAR) at 39\% and the Global Fund at $11 \%$ [12]. Grappling with competing priorities of climate, security, and poverty dims prospects for some countries to increase domestic resources for HIV substantially [12].

The World Bank also contributed substantially to the global HIV response. It committed over US\$ 2 billion to 33 counties through the Multi-Country AIDS 
Table 1 Average annual HIV percent prevalence from 1990 through 2017, public HIV spending in 2017, and IMF credit burden in sub-Saharan Africa in 2019 Data source World Bank [13]*; UNAIDS [12]**; World Bank [7]***

\begin{tabular}{|c|c|c|c|c|c|c|}
\hline \multirow[t]{2}{*}{ Countries } & \multicolumn{2}{|c|}{$\begin{array}{l}\text { HIV percent } \\
\text { prevalence* }\end{array}$} & \multicolumn{2}{|c|}{$\begin{array}{l}\text { HIV percent } \\
\text { prevalence } \\
\text { between } 1990 \text { and } \\
2017^{*}\end{array}$} & \multirow[t]{2}{*}{$\begin{array}{l}\text { Public HIV spend- } \\
\text { ing (US\$ millions) in } \\
2017^{* *}\end{array}$} & \multirow[t]{2}{*}{$\begin{array}{l}\text { IMF credit burden } \\
\text { (US\$ millions in } \\
2019)^{* * *}\end{array}$} \\
\hline & 1990 & 2017 & Mean & Variance & & \\
\hline Eswatini & 1.7 & 27.4 & 22.21 & 66.41 & 33.155 & 69 \\
\hline Botswana & 6.1 & 22.8 & 21.89 & 29.08 & 299.023 & 82 \\
\hline Zimbabwe & 15.9 & 13.3 & 19.60 & 24.65 & 34.348 & 482 \\
\hline Zambia & 8.4 & 11.5 & 13.10 & 3.34 & 15.829 & 794 \\
\hline South Africa & 0.6 & 18.8 & 13.08 & 39.40 & 1545.827 & 2543 \\
\hline Malawi & 6 & 9.6 & 11.70 & 5.02 & 5.594 & 319 \\
\hline Namibia & 2 & 12.1 & 11.37 & 13.56 & 111.050 & - \\
\hline Mozambique & 1.6 & 12.5 & 9.77 & 16.48 & 8.502 & 343 \\
\hline Uganda & 10.7 & 5.9 & 7.49 & 2.29 & 38.693 & 246 \\
\hline Kenya & 5.5 & 4.8 & 7.23 & 3.37 & 342.351 & 1047 \\
\hline $\begin{array}{l}\text { Central African Repub- } \\
\text { lic }\end{array}$ & 3.5 & 4 & 6.47 & 4.41 & 1.892 & 235 \\
\hline Tanzania & 4.9 & 4.5 & 6.41 & 1.85 & 108.120 & - \\
\hline Cote d'Ivoire & 4.1 & 2.8 & 5.37 & 3.81 & 13.736 & 1738 \\
\hline Rwanda & 4.2 & 2.7 & 4.17 & 1.33 & - & 291 \\
\hline Equatorial Guinea & 1 & 6.5 & 4.11 & 3.49 & 7.844 & - \\
\hline Cameroon & 0.9 & 3.7 & 3.86 & 1.57 & 14.806 & 602 \\
\hline Congo, Rep. & 3.2 & 3.1 & 3.78 & 0.39 & 8.104 & 120 \\
\hline Liberia & 4.1 & 1.4 & 3.29 & 2.00 & 0.190 & 402 \\
\hline Nigeria $^{a}$ & 1.2 & 2.8 & 2.95 & 0.48 & 57.729 & 2386 \\
\hline Ethiopia & 1.8 & 0.9 & 2.25 & 0.91 & 54.369 & 301 \\
\hline Burkina Faso & 3.5 & 0.8 & 2.10 & 1.34 & 7.780 & 284 \\
\hline Ghana & 1.1 & 1.7 & 2.08 & 0.18 & 4.679 & 1465 \\
\hline Chad & 1 & 1.3 & 1.71 & 0.12 & 4.623 & 254 \\
\hline Congo, Dem. Rep. & 1.6 & 0.7 & 1.59 & 0.25 & - & 954 \\
\hline Mali & 1 & 1.2 & 1.39 & 0.02 & 6.136 & 334 \\
\hline Angola & 0.2 & 1.9 & 1.20 & 0.35 & 3.296 & 389 \\
\hline Sierra Leone & 0.1 & 1.4 & 1.08 & 0.29 & 0.169 & 509 \\
\hline Benin & 0.2 & 1 & 1.06 & 0.11 & 6.423 & 226 \\
\hline Eritrea & 0.5 & 0.6 & 1.05 & 0.15 & 1.217 & 22 \\
\hline Senegal & 0.2 & 0.4 & 0.53 & 0.03 & 1.921 & 283 \\
\hline Niger & 0.2 & 0.3 & 0.51 & 0.02 & .246 & 287 \\
\hline
\end{tabular}

${ }^{\mathrm{a}} \mathrm{HIV}$ prevalence in Nigeria was about $1.4 \%$ in 2019 [11] 
Programme since 2000 [14]. The Africa Development Bank (AfDB) and other international finance institutions may need to do more. Financing gaps and systemic inefficiencies in LMICs threaten accomplishing universal HIV antiretroviral treatment and viral suppression.

According to UNAIDS [12], sub-Saharan Africa fell short of universal HIV diagnostic testing by 4.3 million people in 2017 ( 1.7 million in east and southern Africa, and 2.6 million in west and central Africa). Universal antiretroviral treatment in 2017 fell short by 5.5 million people ( 3 million in east and southern Africa, and 2.5 million in west and central Africa). For people living with HIV in 2017, 6.7 million had not achieved viral suppression (4 million in east and southern Africa, and 2.7 million in west and central Africa). Because HIV management requires medical treatment that burdens the economies in the region, for sub-Saharan Africa to achieve sustainable financing and accomplish meeting the targets, much remains to be done [15].

\section{Debt profile of sub-Saharan Africa}

The World Bank International Debt Statistics report [7] shows net financial flows to LMICs rose to the highest levels in 2017 (61\%) — driven by 'net debt inflows' of US\$297 billion in short-term loans. Inflows more than tripled in 2017 and surpassed 'net equity' for the first time since 2013 [7]. Seventeen African countries exceeded 60\% debt-to-GDP ratio in 2017 (as defined by the African Monetary Cooperation Program (AMCP) for developing countries) [16]. The number of countries increases to 24 if one applies the 55\% 'debt-to-GDP ratio threshold of the International Monetary Fund'. The debt to GDP ratio indicates capacity to repay debts without risk of further debt-a ratio below $55-60 \%$ is preferable.

The World Bank reported that external debt of sub-Saharan African countries rose by $15.5 \%$ (US $\$ 535$ billion) in 2017 [7]. Nigeria and South Africa account for the sharp rise, by $29 \%$ and $21 \%$, respectively. Thirty sub-Saharan countries benefited from debt relief arrangements under the categories of 'Heavily Indebted Poor Country' (HIPC) and the 'Multilateral Debt Relief initiatives' (MDRI) from 1998 to 2010 [7]. External debt stock in these countries doubled (>90\%) between 2010 and 2015 and rose by $11 \%$ in 2016 [7]. Borrowing from 'non-traditional sources of funds' accounted for over $60 \%$ of long-term debt in sub-Saharan countries in 2017. The World Bank [7] projects that long-term debt there could increase to US $\$ 48$ billion by the end of 2021. Debt service payments could rise sharply or remain high.

The total external debt of each of six sub-Saharan African countries in 2017 exceeded US\$20 billion. For South Africa it exceeded US\$176 billion in 2017; for Nigeria and Angola it totalled US\$40 billion and US\$37 billion, respectively. Other sub-Saharan countries likely face increases. The 'total external debt to gross national income' (GNI) of Mozambique was highest (100.8\%); the ratios in Nigeria, South Africa, Angola, and Ethiopia remained under 60\%. Congo, Liberia, Senegal, Zambia, and Zimbabwe debt-to-GNI exceeded 50\% in 2017 [7].

Nine sub-Saharan African countries (Zambia, South Africa, Sierra Leone, Nigeria, Ghana, Kenya, Cote d'Ivoire, Congo Democratic Republic, and Cameroon) 
each owed the International Monetary Fund (IMF) over US\$500 million (Table 1). The IMF credit of South Africa, Nigeria, Kenya, Ghana, and Cote d'Ivoire collectively exceeded US\$1 billion in 2017 [7]. A debt sustainability analysis of Nigeria's borrowing pattern by the Nigeria Debt Management Office DMO [17] found that its moderate debt distress indicated non-compliance with a debt portfolio indicator (total public debt service to revenue), and represented high risk of distress. The DMO report [17] warned the Government of Nigeria not to exceed the proposed country-specific threshold (25\% up to 2020) in 2018. Total external debt repayments of Nigeria in 2018 showed that Commercial (70.03\%), Multilateral (16.92\%), and Bilateral (10.21\%) sources accounted for most [18].

Historical debt relief measures from the early 2000s eliminated $100 \%$ of external debt owed to Bretton Woods institutions and Paris Club creditors in 36 countries, 30 were in Africa [19]. Today, many of the African countries that benefited 20 years back have reached risk levels of 'debt distress'. Future negotiations for debt relief will be quite different from those of two decades ago. African countries currently owe much accumulated external debt to private creditors [19]. Although debt relief contributed to economic growth, efficient use of these funds remains an issue of debate. As Sambira put it, African countries had to embrace transparency, report on progress of economic and social policies, and reduce aggressive borrowing to access debt relief from the IMF [20].

\section{HIV funding support required in sub-Saharan Africa}

Because appropriate treatment of people living with HIV anywhere in the world could end HIV as a public health concern by 2030 [21], the cost of treatment for a person living with HIV is crucial: it has dropped to an average of US\$150 per year $[21,22]$. Even so, the estimated cost of antiretroviral therapy in sub-Saharan Africa annually is huge (>US\$ 4.7 trillion). This cost is derived from the number of persons requiring treatment using the national HIV prevalence, and the cost of treating one person annually (Table 2). A sustained supply of antiretroviral therapy would be required to avert AIDS related deaths, prevent an increased requirement of second line regimens, prevent new infections, and avert associated care-related costs.

Understanding the annual cost could help achieve cost-savings, efficiency, and better outcomes in planning HIV treatment interventions [15]. International development partners providing technical support to African countries already apply performance-based financing by in some sub-Saharan countries [23-26]; doing so for HIV treatment could help achieve sustainable results.

Embarking on debt service payments and economic development at the same time is not sustainable for many African countries and may have a negative impact on health spending. The trend of health expenditure per capita in sub-Saharan African countries is falling (Table 2). Except for Ethiopia, the annual rate of health expenditure per capita dropped-notably in Angola, Mozambique, Nigeria, and Uganda. If health expenditure per capita is to increase substantially in this region, so too should resources. External support may be required. The decreasing trend of 


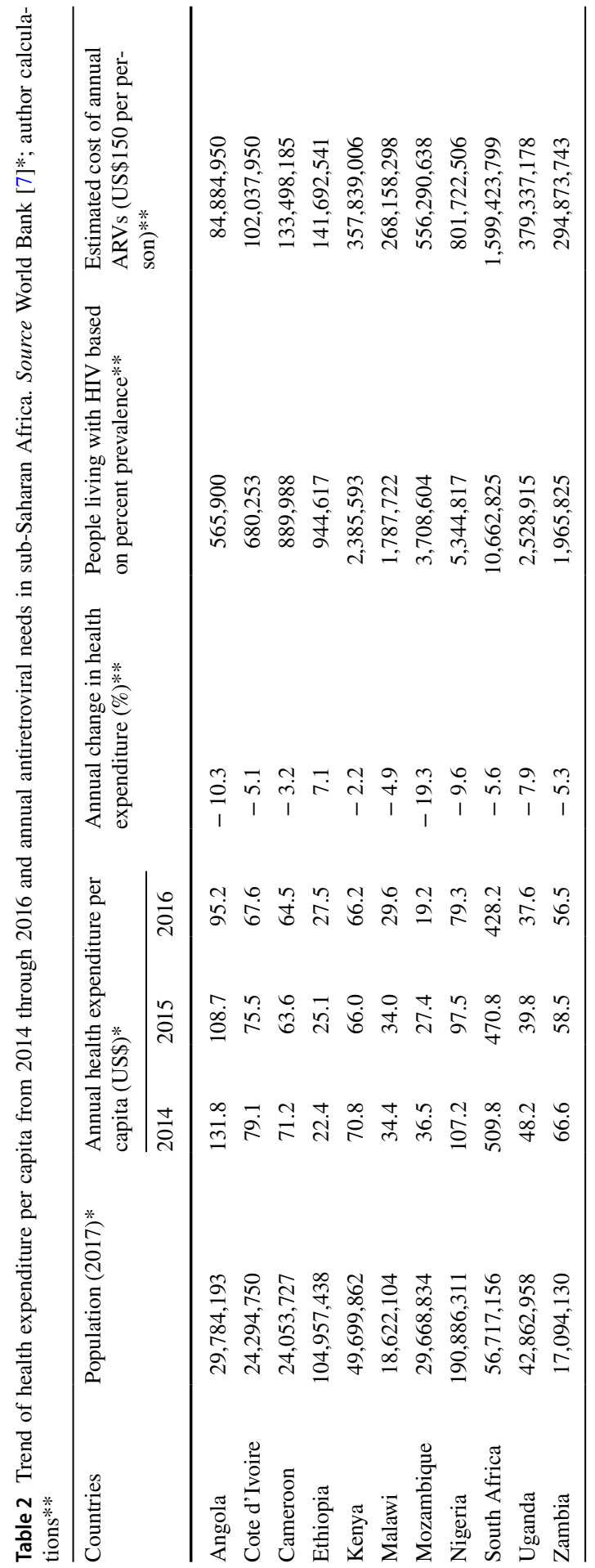


health expenditure may lead to a rise in household out-of-pocket expenditure and weaken potential for attaining universal health coverage in sub-Saharan Africa.

\section{Discussion}

Although the HIV epidemic in Africa may be declining, the next phase will require a sustained supply of antiretroviral drugs, management of complications and opportunistic infections, and laboratory-based appraisals. HIV interventions began in Africa over 30 years ago. Yet, in-country peculiarities and complexities burden management of HIV. Inadequate prevention coverage for key populations and inadequate funding remain key issues in sub-Saharan Africa [12]. Expanding coverage of antiretroviral treatment has been reducing AIDS related mortality and HIV incidence but increasing prevalence [10]. Even as the cost of managing each HIV client for a year may be dropping [15], the financial implications are major for many LMICs with high prevalence of HIV. Most of those (23 of 28) directed less than $50 \%$ of total spending for HIV interventions to care and treatment. Granich et al. linked reduced AIDS related death to sustained treatment and care [8].

Disparity persists in the pace of response to the epidemic. For those living with HIV in west and central Africa, antiretroviral treatment reached about 28\% in 2017; for east and southern Africa, about 54\%. Decline of new infections among children in west and central Africa was 31\% in 2017, and 66\% in east and southern Africa [27]. If Africa is to meet the global targets for the AIDS epidemic by 2030, the WHO's guidance, to commence antiretroviral treatment at diagnosis regardless of CD4 count should be implemented-and with urgency. Health systems in subSaharan African countries are weak, and some overstretched. Capacity to adequately monitor progress of HIV interventions is still developing [28].

According to Kharsani and Karim [29], addressing funding constraints, reducing cost of interventions, simplifying treatment, and strengthening health systems would advance universal coverage of antiretroviral treatment substantially and reduce variability across sub-Saharan countries. Micah et al. [1] note that national policies are important determinants of health sector funding, but with obvious limitations; thus, the global community needs to help stimulate domestic government health spending in this region. Unsustainable spending on health by countries could strain household budgets to cover healthcare and other essentials - further deteriorating public health.

It would require high-level advocacy by global and regional development groups and firm conviction by all stakeholders to eliminate the burden of infectious diseases in Africa for the greater good of the world. Relief from debt service payments could ease the strains. Debt relief funds could replace dwindling donor investments in HIV infrastructure-in a sustainable way, meaning inclusion of standard antiretroviral manufacturing centres, HIV research centres, and other supportive structures. Effective performance-based financing arrangements and globally agreed sanctions might ensure compliance with terms for fund utilization. Collaboration of public and private sector institutions could yield efficiency. Also worth exploring are other policies to increase national HIV spending: priority legislative budgetary appropriation, 'soft taxes' (arrived at through negotiation with stakeholders to raise additional 
intervention funds, with terms subject to bargaining and influence of policy makers) on luxury items, and waivers for importation of HIV-related equipment and commodities. Any agreements require firm commitments and structures to promote accountability and transparency in spending.

Varying risk levels of unsustainable financing capacity exists in sub-Saharan Africa [30]. Stakeholders need to consider country-by-country needs and peculiarities based on economic strength, levels of indebtedness, and creditor preferences. Revealing micro-level information could promote more detailed analysis of support required and might point to sustainable gains for creditors and sub-Saharan countries. As hinted in Sandford [31] and Omotola and Saliu [32], what happens during debt forgiveness is critical as the desired results of debt relief mechanisms are not automatic. This means sub-Saharan African countries should increase accountability, reduce subsidies on consumption, combat corruption, and manage their economies adequately to attract external investments.

\section{Recommendations: pathways for using debt relief for HIV treatment}

In 2014, the WHO [4] made three recommendations for improved financial risk protection and expansion of universal health care in Africa including better strategies for health finance, promotion of pooling arrangements to share financial risks across whole populations, and implementation of equity funds to cover health services for vulnerable populations not able to contribute. Sub-Saharan countries need to avoid increasing household out-of-pocket expenditure for health by increasing health expenditure per capita.

Sub-Saharan Africa needs international support to secure new arrangements, negotiated country-by-country, grounded on performance-based financing and credible commitments by each nation to accountability, transparency, efficiency. Debt relief could incentivize African countries to convert debt repayment funds to assure HIV treatment for all persons living with HIV. Now is the time to ensure local capacity development for effective management of HIV. Capacities developed as a result of the HIV response in many countries have already advanced management of other major diseases including malaria, tuberculosis, Ebola, and COVID-19 and promise future benefits by using overlapping strategies, equipment, resources, and trained personnel. Coordination of performance-based debt relief for HIV treatment will be most effective if placed under the office of the President in sub-Saharan countries, with oversight from creditors (all entities that owned debts by sub-Saharan African countries or that have financial capacity to lend to sub-Saharan African countries).

There should be systems to collect accurate information for debt relief eligibility, country-by-country. Analysis of previous debt relief experience and problems could point to ways to avoid repeating inefficient practices. Stakeholders should work with creditors to agree upon a period of time, at least 5 years, during which they suspend loan repayments to free resources for HIV treatment, including a sustainable supply of all commodities at HIV treatment facilities. The planning should include local arrangements for redirecting debt relief funds to remove dependence of national HIV treatment programmes on donor funding. 
Plans should address other challenges identified through research on national HIV treatment programmes including weak human resource capacity, poor salaries, and compensatory allowances at HIV treatment facilities, staff attrition, and inadequate resources.

Debt relief planning could drive inclusion of HIV treatment in budgeting at all levels of governance and in health insurance schemes to improve sustainability of HIV treatment after the debt relief phase. Good planning would engage women in HIV decision-making and policy implementation at all levels to address genderrelated HIV and socioeconomic issues of all those living with HIV.

\section{Conclusion}

Africa's capacity to keep pace with the global movement to achieve HIV targets by 2030 is weak because many countries, especially in sub-Saharan Africa, carry crippling debt and are unable to fund the needed interventions. If the precarious financial situation in sub-Saharan Africa persists, the HIV burden in Africa and its negative influence on development could deepen. Sub-Saharan African countries are especially vulnerable to other natural and environmental disasters, including the COVID-19 pandemic. Reducing debt or debt service repayment could help redirect funds into innovative performance-based health financing to accelerate and sustain HIV antiretroviral treatment to achieve HIV targets by 2030.

\section{Glossary of terms and concepts}

\section{Terms in the Introduction}

Concessional financing: Loans obtained by governments from financial groups (see: https://www.imf.org/external/about/lending.htm) or institutions with extended terms and grace periods which are more generous than loans with prevailing market conditions.

Revenue to gross domestic product (GDP): The ratio of a country's tax and nontax revenue to gross domestic product compares the total national income generated by a country with the monetary value of all goods and services within the country at a given time (economy size).

Expenditure to gross domestic product (GDP): The ratio of a country's expenditure to gross domestic product compares government spending including loan repayments with the size of economy in the country within a given time. If a high percentage of government spending is on parameters of public liabilities, it may have limited capacity to sustain development (see: https://www.imf.org/external/datam apper/exp).

International capital markets: Global financial centres or capital market platforms for international trade in shares, currencies, and other long-term securities.

The debt sustainability classification: A classification of countries based on capacity to sustain public debt repayments. The classification is based on the IMF 
methods for debt sustainability assessment (see: https:/www.imf.org/external/pubs/ $\mathrm{ft} / \mathrm{dsa} /$ ) which tests the current debt situation, vulnerabilities in the debt structure, and potential impact of debt-stabilization policies where repayment difficulties are evident or imminent. Debt service difficulties are measured by 'debt distress' risk levels (low, medium, high) which indicate a country's inability to adequately sustain loan repayment conditions (see: https://www.imf.org/en/About/Factsheets/Sheet s/2016/08/01/16/39/Debt-Sustainability-Framework-for-Low-Income-Countries).

Deficit financing: A situation where government spending is higher than its receipts and largely financed with borrowed funds (see: https://www.britannica.com/ topic/deficit-financing).

Public debt: The total debt stock the government of a country owes external lenders.

Innovative financing: The term refers to unusual methods of fund raising by government or stakeholders for additional resources to bridge intervention gaps. An example could be public-private partnership projects.

\section{Terms in the Methods section}

Health expenditure per capita: This is expenditure by government on individual and general health services. The annual rate of change in health expenditure per capita is influenced by social and economic factors, revenue generation, and quality of the available health system (see: https://www.oecd-ilibrary.org/docserver/health_glanc e-2015-59-en.pdf).

Low and middle-income countries (LMICs): The World Bank classifies all its members for ease of aggregation, statistical comparison, and presentation of key information. The income classification group is based on gross national income (GNI) and are low (GNI per capita of $\$ 1025$ or less in 2018), lower-middle (GNI per capita between $\$ 1026$ and \$3995), upper-middle (GNI per capita between $\$ 3996$ and \$12,375), and high (GNI per capita of \$12,376 or more). Sub-Saharan African countries fall within the low- and middle-income category (see: https://datahelpde sk.worldbank.org/knowledgebase/articles/906519-world-bank-country-and-lendinggroups).

\section{Terms in the section-Results}

\section{Subsection: Debt profile of sub-Saharan Africa}

Net debt inflows: This measures the amount of government debt that is outstanding, the changes in levels and flows into a country over time, and whether government debt is becoming a concern.

Net equity: Known also as 'net income', this includes the sum total of external income into a country at a given time minus liabilities.

Debt to gross domestic product (GDP): The debt-to-GDP ratio (see: https://www. investopedia.com/terms/d/debtgdpratio.asp) measures a country's total public debt with its gross domestic product (GDP). It is commonly used to assess a country's 
capacity to repay external loans without significantly hindering economic development. A high debt-to-GDP ratio is usually undesirable.

Debt-to-GDP ratio threshold of the International Monetary Fund (IMF): This is a debt-to-GDP sustainability threshold (see: https://www.imf.org/en/About/Facts heets/Sheets/2016/08/01/16/39/Debt-Sustainability-Framework-for-Low-Incom e-Countries) recommended by the IMF to countries in various income groups for self-assessment regarding status of indebtedness and capacity to sustain debt service payments.

Heavily Indebted Poor Country (HIPC): The HIPC Initiative (see: https://www. imf.org/en/About/Factsheets/Sheets/2016/08/01/16/11/Debt-Relief-Under-the-Heavi ly-Indebted-Poor-Countries-Initiative) was launched in 1996 by the IMF and World Bank to minimize the risk of over indebtedness by poor countries, and to galvanize the international financial community to promote sustainable levels of external debt. This categorization was used in 1999 to provide debt relief to poor countries. For low resource countries to qualify for HIPC categorization, they were required to meet criteria by the IMF and World Bank including committing to poverty reduction through clear policy changes, and demonstrating a consistent implementation relevant policies over time.

Multilateral Debt Relief Initiative (MDRI): The MDRI (see: https://www.imf.org/ external/np/exr/facts/mdri.htm) was introduced in 2005 to support countries participating in the HIPC Initiative in meeting poverty targets of the United Nations Millennium Development Goals (MDGs) by 2015. Three multilateral financial institutions (IMF, World Bank, and AfDF) provided 100\% relief on eligible debt for lowincome countries in the HIPC Initiative.

Non-traditional sources of loans: Loans with market rate conditions sourced from alternative lending entities such as governments, financial groups or institutions that are not effectively regulated by international financing frameworks.

Debt service payments: Debt service payment connotes the amount required to offset debt interest and principal at a given period which could be annual, quarterly, or monthly.

Total debt to gross national income (GNI): The external debt-to-GNI ratio (see: https://www.indexmundi.com/facts/indicators) measures a nation's burden of external debt against its foreign currency earning capacity to be able to repay the debts. Total external debt includes the liabilities of the public sector such public debt, publicly guaranteed debt, and private non-guaranteed long-term debt, use of IMF credit, and short-term debt.

Debt portfolio indicators: Indicators used by governments when carrying out debt sustainability analysis to measure vulnerability of debt portfolios against market, credit, and reputational risks.

Country-specific thresholds: Borrowing limits self-imposed by governments within the recommended international thresholds by the International Monetary Fund (IMF) -- to control external borrowing and ensure repayment sustainability.

Total external debt repayments: Total external debt is the percentage of a nation's debt sourced from external lender including financial (commercial) banks, governments (bilateral), or international (multilateral) financial institutions. Payments conditions to service the debt are usually part of debt negotiation. 
Bretton Woods institutions: This refers to the World Bank and the International Monetary Fund (IMF), both established at a meeting of 43 countries in Bretton Woods, New Hampshire, USA in July 1944 (see: https://www.brettonwoodsproject. org/2019/). These institutions have grown in membership and promote international economic cooperation frameworks.

Paris Club creditors: A group of informally bound creditor countries (19 permanent members) known as the Paris Club (see: https:/www.investopedia.com/terms /p/parisclub.asp) that aim to arrive at common approaches to solving issues faced by debt defaulting countries.

HIV funding: This is referring to HIV funds provided by Donor countries and International Development Partners to support HIV interventions in developing countries.

\section{References}

1. Micah AE, Chen CS, Zlavog BS, Hashimi G, Chapin A, Dieleman JL. Trends and drivers of government health spending in sub-Saharan Africa, 1995-2015. BMJ Glob Health. 2019;4(1):e001159.

2. Cook N, Arieff A, Blanchard LP, Williams BR, Husted TF. Sub-Saharan Africa: key issues, challenges, and U.S. responses, congressional research service report [Internet]. 2017. https://fas.org/ sgp/crs/row/R44793.pdf.

3. GBCHealth mission, Aliko Dangote Foundation, UNECA. Healthcare and economic growth in Africa, High-level dialogue on Africa's Health and Financing: pathways to economic growth and prosperity, New York [Internet]. 2018. https://allafrica.com/stories/201810020639.html.

4. WHO-World Health Organisation. African region expenditure atlas [Internet]. 2014. https://www. afro.who.int/sites/default/files/2017-06/who-african-region-expenditure-atlas_-november-2014.pdf.

5. AfDB-African Development Bank. Africa economic outlook 2018 [Internet]. 2018. https://www. afdb.org/en/knowledge/publications/african-economic-outlook/.

6. AfDB-African Development Bank. Africa economic outlook 2019 [Internet]. 2019. https://www. afdb.org/en/knowledge/publications/african-economic-outlook/.

7. World Bank. International debts statistics [Internet]. 2019. https://data.worldbank.org/products/ids.

8. Granich R, Gupta S, Montaner J, Williams B, Zuniga JM. Pattern, determinants, and impact of HIV spending on care and treatment in 38 high-burden low- and middle-income countries. J Int Assoc Provid AIDS Care. 2016;15(2):91-100.

9. NACA-National Agency for the Control of AIDS. HIV/AIDS policy \& advocacy newsletter, quarter 12018 [Internet]. 2018. https://naca.gov.ng/wp-content/uploads/2018/05/NACA-HIV-Polic y-Advocacy-Newsletter_Q1-2018.pdf.

10. Dwyer-Lindgren L, Cork MA, Sligar A, Steuben KM, Wilson KF, Provost NR, Mayala BK, VanderHeide JD, Collison ML, Hall JB, Biehl MH, Carter A, Frank T, Douwes-Schultz D, Burstein R, Casey DC, Deshpande A, Earl L, El Bcheraoui C, Farag TH, Henry NJ, Kinyoki D, Marczak LB, Nixon MR, Osgood-Zimmerman A, Pigott D, Reiner RC, Ross JM, Schaeffer LE, Smith DL, Weaver ND, Wiens KE, Eaton JW, Justman JE, Opio A, Sartorius B, Tanser F, Wabiri N, Piot P, Murray CJL, Hay SI. Mapping HIV prevalence in sub-Saharan Africa between 2000 and 2017. Nature. 2019. https://doi.org/10.1038/s41586-019-1200-9.

11. FMOH-Federal Ministry of Health. National AIDS Impact and Indicator Survey (NAIIS): press release [Internet]. 2019. https://naca.gov.ng/naiis-press-release/.

12. UNAIDS - Joint United Nations Programme on HIV/AIDS. HIV Data 2018 [Internet]. 2018. https ://www.unaids.org/sites/default/files/media_asset/unaids-data-2018_en.pdf.

13. World Bank. Meeting the challenge: the world bank and HIV/AIDS [Internet]. 2013. http://projectsbeta.worldbank.org/en/results/2013/04/03/hivaids-sector-results-profile.

14. World Bank. Prevalence of HIV, total (\% of population ages 15-49) [Internet]. 2018. https://data. worldbank.org/indicator/sh.dyn.aids.zs. 
15. CDC - Centres for Disease Control and Prevention. HIV cost-effectiveness [Internet]. 2017. https:// www.cdc.gov/hiv/programresources/guidance/costeffectiveness/index.html.

16. Onyekwena C, Okeruche MA. Africa in focus: is a debt crisis looming in Africa[Internet]? 2019. https://www.brookings.edu/blog/africa-in-focus/2019/04/10/is-a-debt-crisis-looming-in-africa/.

17. DMO_-Debt Management Office. Report of the annual national debt sustainability analysis in Nigeria [Internet]. 2017. https://www.dmo.gov.ng/publications/reports/debt-sustainability-analysis.

18. DMO - Debt Management Office. Nigeria's actual external debt service payments in January December, 2018 [Internet]. 2018. https://www.dmo.gov.ng/debt-profile/external-debts/debt-service.

19. Sandefur J, Wadhwa D. Chart of the week: a new African debt crisis [Internet]? 2018. https://www. cgdev.org/blog/chart-of-the-week-new-african-debt-crisis.

20. Sambira J. Borrowing responsibly: Africa's debt challenge. 2015. https://www.un.org/africarenewal/ magazine/august-2015/borrowing-responsibly-africa's-debt-challenge.

21. UNDP-United Nations Development Programme. World AIDS Day: record drop in cost of HIV treatment [Internet]. 2015. https://www.undp.org/content/undp/en/home/presscenter/artic les/2015/11/30/world-aids-day-record-drop-in-cost-of-hiv-treatment.html.

22. Treskova M, Kuhlmann A, Bogner J, Hower M, Heiken H, Stellbrink HJ, Mahlich J, Schulenburg JM, Stoll M. Analysis of contemporary HIV/AIDS health care costs in Germany: driving factors and distribution across antiretroviral therapy lines. Medicine. 2016;95(26):e3961. https://doi. org/10.1097/md.0000000000003961.

23. World Bank. Performance-based financing improves quality of health services in Nigeria [Internet]. 2017. http://www.worldbank.org/en/news/feature/2017/02/16/performance-based-financing-impro ves-quality-of-health-services-in-nigeria.

24. Paul E, Albert L, Bisala BN, Bodson O, Bonnet E, Bossyns P, Colombo S, De Brouwere V, Dumont A, Eclou DS, Gyselinck K, Hane F, Marchal B, Meloni R, Noirhomme M, Noterman JP, Ooms G, Samb OM, Ssengooba F, Touré L, Turcotte-Tremblay AM, Van Belle S, Vinard P, Ridde V. Performance-based financing in low-income and middle-income countries: isn't it time for a rethink? BMJ Glob Health. 2018;3(1):e000664. https://doi.org/10.1136/bmjgh-2017-000664.

25. Ridde V, Gautier L, Turcotte-Tremblay AM, Sieleunou I, Paul E. Performance-based financing in Africa: time to test measures for equity. Int J Health Serv. 2018;48(3):549-61. https://doi. org/10.1177/0020731418779508.

26. Owona Manga LJ, Fouda AAB, Mbida L, Mvogo CE. Performance based financing and job satisfaction in a semi urban health district in Cameroon. J Public Health Afr. 2018;9(760):60-4.

27. Hankins C. Review of HIV in sub-Saharan Africa: current situation, opportunities and challenges. BMJ Glob Health. 2017;2(2):A1-67. https://doi.org/10.1136/bmjgh-2016-000260.4.

28. Goga A. How are countries in sub-Saharan African monitoring the impact of programmes to prevent vertical transmission of HIV? BMJ. 2019;364:1660. https://doi.org/10.1136/bmj.1660.

29. Kharsani ABM, Karim QA. HIV infection and AIDS in sub-Saharan Africa: current status, challenges and opportunities. Open AIDS J. 2016;10:34-48.

30. Mustapha S, Prizzon A. Africa's rising debt: How to avoid a new crisis. Briefing note. 2018. https:// www.odi.org/sites/odi.org.uk/files/resource-documents/12491.pdf.

31. Sandford JE. Africa's debt burden: proposals for further forgiveness. CSIS Africa notes (189) [Internet]. 1996. https://csis-prod.s3.amazonaws.com/s3fs-public/legacy_files/files/publication/anote s_1096.pdf.

32. Omotola JS, Saliu H. Foreign aid, debt relief and Africa's development: problems and prospects. S Afr J Int Aff. 2009;16(1):87-102. https://doi.org/10.1080/10220460902986180.

Publisher's Note Springer Nature remains neutral with regard to jurisdictional claims in published maps and institutional affiliations.

Roland C. Abah was a Chief Programme Officer (Risk and Compliance) at the National Agency for the Control of AIDS, Central Area, Abuja, Nigeria. He is currently with the World Meteorological Organization office in Abuja. This paper is a product of individual research and does not explicitly express the views of any nation or organization mentioned in this paper. 